\title{
Inhibition Studies of Pyrimidine Class of Compounds on Enoyl-Acp Reductase Enzyme
}

\author{
Sunil H. Ganatra ${ }^{1 *}$, Manoj N. Bodhe ${ }^{1}$ and P. N. Tatode ${ }^{2}$
}

${ }^{1}$ Department of Chemistry, Institute of Science, R. T. Road, Civil Lines, Nagpur - 440001, Maharashtra, India

${ }^{2}$ Department of Chemistry, NutanAdarsh Arts, Commerce \& Smt. M.H. Wegad Science College, Umrer, Nagpur, Maharashtra, India

\begin{abstract}
Present work is aimed to identify and understand the inhibiting nature of Pyrimidine class of compounds to enoyl acyl carrier protein reductase (Enoyl-ACP reductase), which is one of the main receptor proteins used in drug discovery for screening anti-leprosy agents.

Series of Pyrimidine based compounds are virtually designed using the molecular mechanic technique. The designed molecules were docked using with crystal structure of Enoyl-ACP reductase (PDB ID: 2NTV) using Autodock molecular docking software.

The method uses rigid-protein and flexible ligand-techniques to acquire maximum conformations of ligand molecules. The docking results were evaluated using the acquired binding energy values for each ligand-protein complex. Those molecules having higher negative binding energy values with higher hydrogen bonds are selected for further analysis.

The selected molecules show better hydrophobic, electrostatic and steric interactions with receptor protein. It is reported that the presence of $-\mathrm{CH}_{2} \mathrm{OH}$ at $\mathrm{R}_{1}$ and $-\mathrm{C}_{6} \mathrm{H}_{5}$ at $\mathrm{R}_{2}$ and $\mathrm{R}_{3}$ positions enhance the negative binding energy $\left(\Delta \mathrm{G} \mathrm{kcal} \mathrm{mol}{ }^{-1}\right.$ ) values. Particularly $-\mathrm{OC}_{6} \mathrm{H}_{5}$ at $\mathrm{R}_{1}$ and $-\mathrm{OH}$ at $\mathrm{R}_{2}$ help in increasing the interactions between ligand and protein. The results show the molecular level interactions and inhibit the receptor protein.
\end{abstract}

Keywords: Leprosy; Molecular modeling; In-silico; Drug discovery; Docking

\section{Introduction}

Leprosy is a chronic disease caused by the bacteria Mycobacterium leprae and Mycobacterium lepromatosis. The disease also known as Hansen's disease (HD) [1,2]. The World health organization (WHO) reported that it is one of the major diseases in developing countries [3]. The disease has its presence in developing countries due to age old social stigma [4]. Patient generally report late and by that time it has already spread at critical level. The effective treatment for the disease appeared in the year 1930s with the introduction of new drug Dapsone and its derivatives. Soon the bacteria develop resistance for the Dapsone and the treatment of Dapsone was turmoil. The medicine problems remained until the introduction of multi drug therapy (MDT) from 1980s. Though this treatment is effective but it is quite expensive. There is urgent need to find new anti-leprosy agents.

Recently Wang et al. [5] reported that Thioamide, Ethionamide (ETH) and Prothionamide (PTH) drugs are clinically effective in the treatment of M. leprae, M. Tuberculosis, and M. Avium complex infections. These drugs are second line drugs for tuberculosis, their use have increased considerably as the number of multidrug resistant cases continues to rise. The crystal structures of the inhibited M. leprae and M. tuberculosis InhA complexes provide (PDB REF. NO: 2NTV) the molecular details of target-drug interactions. It is reported that PTH binds with NAD and this adduct inhibits Mycobacterium leprae (InhA).

The crystal structure provided by Wang et al. [5] can be utilized to try and test new possible inhibitors using molecular modeling techniques. Recent advances in computation chemistry and biological sciences allow the researchers to model and understand drug targets and to discover drugs that are cheaper and safer. The availability of three-dimensional coordinates for target protein enables the use of structure-based drug design techniques. These technologies include virtual screening, pharmacophore development and structure based optimization [6].

Structure-based drug design (SBDD) is one of several methods available with rational drug design. The inhibition of core enzymes result in cessation of diseases symptoms. These enzymes are treated as drug targets. Using various computational tools it is possible to design new chemical entity before it synthesize in the laboratory. This helps in reducing research cost and saves environment by not wasting huge chemicals in finding new molecules in synthesis chemistry laboratory $[6,7]$.

SBDD uses crystal structure of target enzymes in electronic format and virtual drug molecules to understand the inhibition possibilities of designed molecules. The 3D structure of enzyme target is most often derived from $\mathrm{X}$-ray crystallography or nuclear magnetic resonance (NMR) techniques [7-9]. X-ray and NMR methods can resolve the structure of proteins to a resolution of a few angstroms. At this level of resolution, researchers can precisely examine the interactions between atoms in protein targets and atoms in potential drug compounds that bind to the proteins. This ability to work at high resolution with both proteins and drug compounds makes SBDD one of the most powerful methods in drug design $[10,11]$.

*Corresponding author: Sunil H. Ganatra, Department of Chemistry, Institute of Science, R.T. Road, Civil Lines, Nagpur-440001, Maharashrta, India, E-mail: sunilganatra@gmail.com

Received July 05, 2012; Accepted October 26, 2012; Published November 30 2012

Citation: Ganatra SH, Bodhe MN, Tatode PN (2013) Inhibition Studies of Pyrimidine Class of Compounds on Enoyl-Acp Reductase Enzyme. J Comput Sci Syst Biol 6: 025-034. doi:10.4172/jcsb.1000097

Copyright: (c) 2013 Ganatra SH, et al. This is an open-access article distributed under the terms of the Creative Commons Attribution License,which permits unrestricted use, distribution, and reproduction in any medium, provided the original author and source are credited. 
Citation: Ganatra SH, Bodhe MN, Tatode PN (2013) Inhibition Studies of Pyrimidine Class of Compounds on Enoyl-Acp Reductase Enzyme. J Comput Sci Syst Biol 6: 025-034. doi:10.4172/jcsb.1000097

\section{Targeting the Enoyl-ACP reductase enzyme}

Enoyl-acyl carrier protein reductase is a key enzyme of the type II fatty acid synthesis (FAS) system. It is an attractive target for narrowspectrum antibacterial drug discovery because of its essential role in metabolism and its sequence conservation across many bacterial species [12].

An enoyl-[acyl-carrier-protein] reductase (NADPH, A-specific) is an enzyme that catalyzes the chemical reaction as depicted in equation 1. This enzyme belongs to the family of oxidoreductases, those enzymes which act on the $\mathrm{CH}-\mathrm{CH}$ group of donor with $\mathrm{NAD}^{+}$or $\mathrm{NADP}^{+}$as an acceptor [13]. The systematic name of this enzyme class is acyl-[acylcarrier-protein]: $\mathrm{NADP}^{+}$oxidoreductase (A-specific).

$$
\begin{aligned}
& \text { acyl }-[\text { acyl }- \text { carrier }- \text { protein }]+N A D P^{+} \stackrel{-}{\leftarrow} \text { trans }-2,3- \\
& \text { dehydroacyl }-[\text { acyl }- \text { carrier }- \text { protein }]+N A D P H+H^{+}
\end{aligned}
$$

As per equation 1, the two substrates of this enzyme are [[acyl[acyl-carrier-protein]]] and $N A D P^{+}$, whereas it gives 3 products and they are [[trans-2,3-dehydroacyl-[acyl-carrier-protein]]], NADPH, and $H^{+}$

The aim of the present study is to understand the inhibition possibilities and interaction details between Pyrimidine class of compounds and Enoyl-ACP reductase enzyme using molecular modeling techniques. Also utilizing the structure based drug design techniques, evaluate the possible conformations of small molecules and their binding energies with Enoyl-ACP Reductase enzyme (Crystal structure having PDF reference number 2NTV). Also to rank the best three molecules are evaluated on the basis of binding energy, cluster size and possibilities of hydrogen bond.

\section{Materials and Methods}

\section{Preparation of receptor enzyme}

The selected enzyme is Enoyl-ACP reductase whose crystal structures are available online and one of them has PDBREF. NO. $2 N T V$. The structure was downloaded from online protein data bank $[14,15]$. The enzyme is the product of $i n h A$ gene which plays important role in Mycolic acid biosynthesis. The selected 3D structure of enzyme was having natural inhibitor 2-propyl-isonicotinic-acyl-nicotinamideadenine dinucleotide. It is also reffered as PTH-NAD adduct [5].

The 3-D structure of enzyme is generally not complete. It needs the exhaustive checking for the missing bonds and atoms. Using the computer based Autodock tools these anomalies were removed and corrected for 2NTV. This is done only in binding site, as it is the place under investigation for the interactions with ligand.

The solvation process was performed followed by preparation of enzyme grid for docking process using AutoDock [16].

\section{Selection of binding site}

To understand the inhibition possibilities, the designed small molecule should be placed in the selected active site of the enzyme. The place is also called as Motif. The motif is the active site consisting of enzyme folding where the drug actually interacts with the amino acids of enzyme. Figure 1 depicts the selected active site and also list amino acids involves in active sites whereas figure 2 shows the 2-D and 3-D structure of natural inhibitor in enzyme.

\section{Small molecule preparation and verification (Ligand preparation)}

Library of compounds (also known as Small molecule or Ligand) belongs to Pyrimidine class which were designed using computational tools. Chem Office software provides varieties of tools to design valid 2-D and 3-D structures [17]. Computational methods like molecular mechanics and energy minimizations are employed for generating 2-D

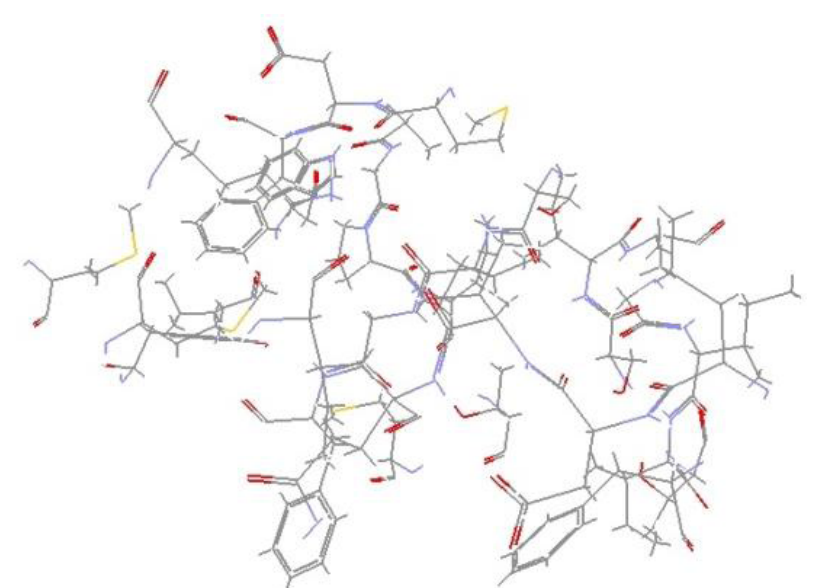

22-Alanine, 191-Alanine, 65-Aspartic Acid, 148-Aspartic Acid, 66- Glutamine, 14-Glycine, 192-Glycine, 15-Isoleucine, 16-Isoleucine, 21-Isoleucine, 95-Isoleucine, 122-Isoleucine, 194-Isoleucine, 63-Leucine, 218-Leucine, 165-Lysine, 147-Methianine, 155-Methianine, 161-Methianine, 199-Methianine, 41-Phenylalnine, 97-Phenylalnine, 149-Phenylalnine, 193-Proline, 20-Serine, 94-Serine, 17-Threonine, 196-Threonine

Figure 1: 3-D structure of Enoyl-ACP Reductase. (2NTV) active site and list of amino acids involved in designing active site [5].

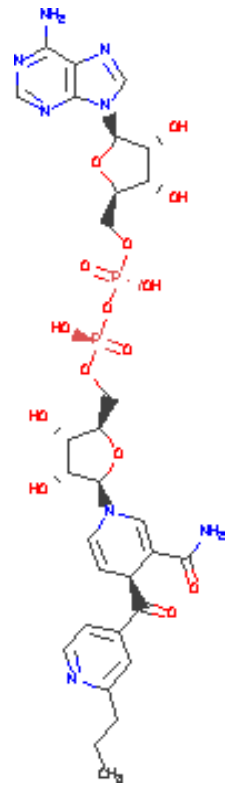

2-D Structure

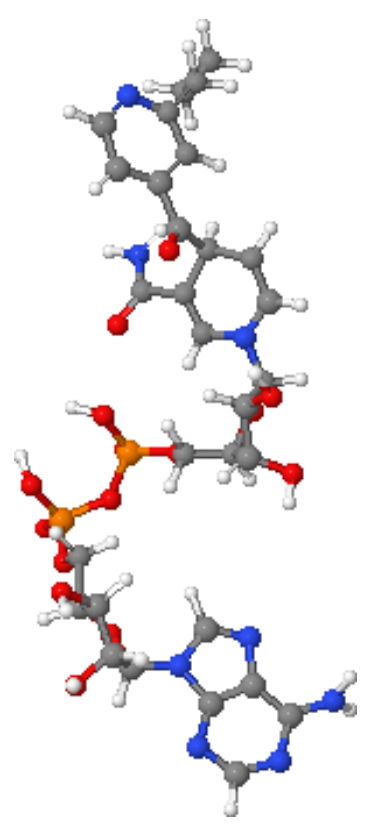

3-D Structure
Figure 2: 2-D and 3-D structure of 2-propyl-isonicotinic-acyl-nicotinamideadenine dinucleotide (natural inhibitor) in the active site of 2NTV enzyme [5]. 
<smiles>[R]c1cc([R])nc([R])n1</smiles>

Figure 3: Lead compound: Substituted pyrimidine.

and 3-D structures of small molecules [18,19]. All designed structures initiated from Substituted Pyrimidine which is the basic structure of lead compound. Its general structure is depicted in figure 3. All the designed molecules are Pyrimidine based on the difference in their pharmacophore attached at various substation positions in the lead compound.

The designed molecules were sterically modified to confirm the global minima of the same. The 3-D geometry optimizations were done using semi-empirical QM/MM techniques $[18,19]$.The energy minimization process performed until the geometry of the molecules reaches to the global minimum energies. This is done by distorting the 3-D structure prepared by QM.MM until same minimum energy was reported. The list of compounds designed along with various substitutions and their 2-D structures is reported in table 1.

2-D and 3-D properties of designed compounds are calculated and listed in tables 2 and 3 respectively. These are computational properties and calculated using Chem Office Software. The 2-D properties of designed molecules indicate the probabilities of drug-likeness in designed compound. The 3-D properties are the various energies reported while finalizing the geometry of the compound. Minimum total energies of the compounds support the stability of compound in the selected conformation [17].

\section{Docking process}

AUTODOCK [16] is widely used computer based tools to process virtual docking of small molecules (ligand) with enzyme. This program has number of tools to perform the docking process. The detailed

\begin{tabular}{|c|c|c|c|c|c|}
\hline Mol. No. & Molecular Formula & R1 & R2 & R3 & 2D-Structure \\
\hline 1 & $\mathrm{C}_{11} \mathrm{H}_{10} \mathrm{~N}_{2} \mathrm{~S}$ & $-\mathrm{SH}$ & $-\mathrm{C}_{6} \mathrm{H}_{5}$ & $-\mathrm{CH}_{3}$ & \\
\hline 2 & $\mathrm{C}_{11} \mathrm{H}_{10} \mathrm{~N}_{2} \mathrm{~S}$ & $-\mathrm{SH}$ & $-\mathrm{CH}_{3}$ & $-\mathrm{C}_{6} \mathrm{H}_{5}$ & \\
\hline 3 & $\mathrm{C}_{11} \mathrm{H}_{10} \mathrm{~N}_{2} \mathrm{~S}$ & $-\mathrm{CH}_{3}$ & $-\mathrm{C}_{6} \mathrm{H}_{5}$ & $-\mathrm{SH}$ & \\
\hline 4 & $\mathrm{C}_{12} \mathrm{H}_{12} \mathrm{~N}_{2} \mathrm{OS}$ & $-\mathrm{SH}$ & $-\mathrm{C}_{6} \mathrm{H}_{4} \mathrm{OCH}_{3}$ & $-\mathrm{CH}_{3}$ & \\
\hline 5 & $\mathrm{C}_{11} \mathrm{H}_{10} \mathrm{~N}_{2} \mathrm{OS}$ & $-\mathrm{SH}$ & $-\mathrm{C}_{6} \mathrm{H}_{5}$ & $-\mathrm{OCH}_{3}$ & \\
\hline
\end{tabular}


Citation: Ganatra SH, Bodhe MN, Tatode PN (2013) Inhibition Studies of Pyrimidine Class of Compounds on Enoyl-Acp Reductase Enzyme. J Comput Sci Syst Biol 6: 025-034. doi:10.4172/jcsb.1000097

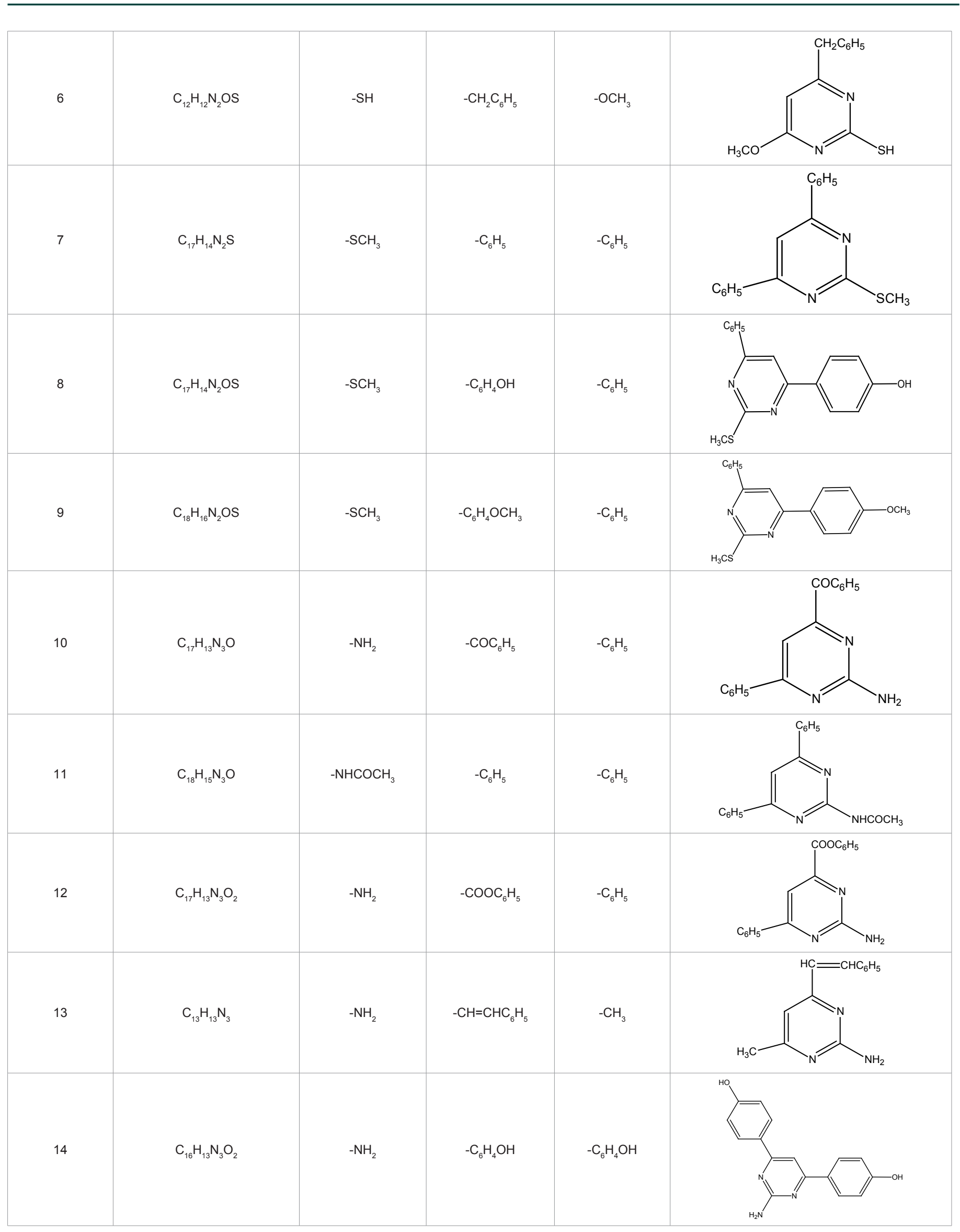


Citation: Ganatra SH, Bodhe MN, Tatode PN (2013) Inhibition Studies of Pyrimidine Class of Compounds on Enoyl-Acp Reductase Enzyme. J Comput Sci Syst Biol 6: 025-034. doi:10.4172/jcsb.1000097

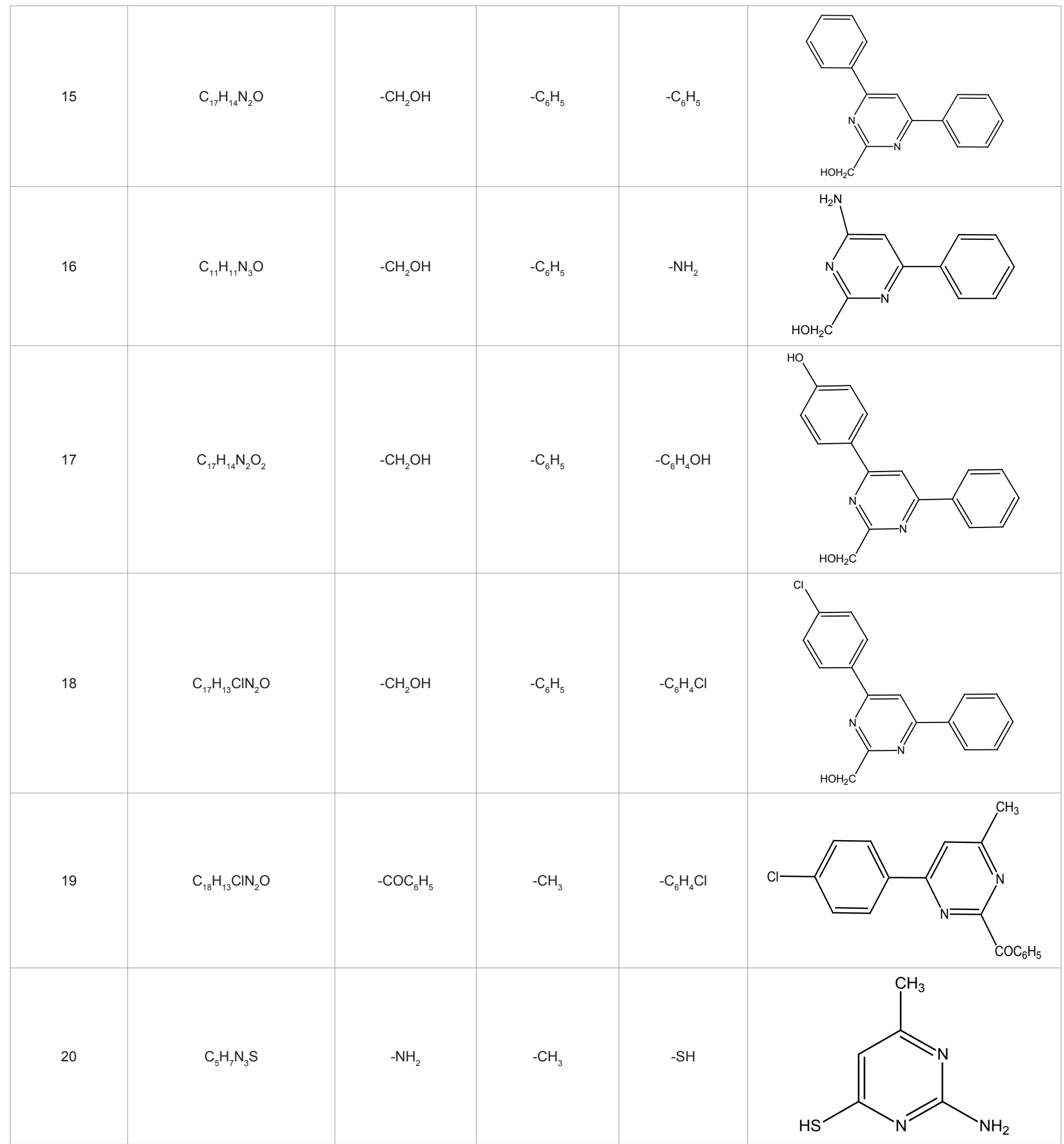

Table 1: List of Pyrimidine class of molecules designed along with their position of substation group and structural formula.

docking method is explained in AUTODOCK user guide [20]. Table 4 depicts the detail of hardware and software used for executing AUTODOCK. The working of installed system and software were tested with the known ligand+protein interactions as described in Autodock user manual [20].

In present study two types of docking were performed: i) Docking process using Non-genetic algorithm (NON-GA)

ii) Docking process using Genetic algorithm (GA)

Nowdays, various artificial intelligence algorithms are used for docking to bring the best results. Genetic algorithm (GA) is one of the intelligence search algorithms used with docking software. It searches 
Citation: Ganatra SH, Bodhe MN, Tatode PN (2013) Inhibition Studies of Pyrimidine Class of Compounds on Enoyl-Acp Reductase Enzyme. J Comput Sci Syst Biol 6: 025-034. doi:10.4172/jcsb.1000097

\begin{tabular}{|c|c|c|c|c|c|c|c|c|}
\hline \multirow[b]{2}{*}{ Mol. No. } & \multirow{2}{*}{$\begin{array}{l}\text { Molecular } \\
\text { Formula }\end{array}$} & \multicolumn{3}{|c|}{ LogP By } & \multicolumn{2}{|c|}{ Molar Refractivity } & \multirow{2}{*}{$\begin{array}{l}\text { Boiling } \\
\text { Point } \\
\text { (K) }\end{array}$} & \multirow{2}{*}{$\begin{array}{c}\text { Gibb's Energy } \\
\text { (Kj/Mol) }\end{array}$} \\
\hline & & $\begin{array}{c}\text { Crippen's } \\
\text { Fragmentation }\end{array}$ & $\begin{array}{l}\text { Vishwanathan's } \\
\text { Fragmentation }\end{array}$ & $\begin{array}{c}\text { Broto's } \\
\text { Fragmentation }\end{array}$ & $\begin{array}{l}\text { Crippen's } \\
\text { Method }\end{array}$ & $\begin{array}{l}\text { Vishwanathan's } \\
\text { Method }\end{array}$ & & \\
\hline 1 & $\mathrm{C}_{11} \mathrm{H}_{10} \mathrm{~N}_{2} \mathrm{~S}$ & 3.60 & 3.28 & 2.62 & 60.49 & 60.44 & 603.81 & 430.79 \\
\hline 2 & $\mathrm{C}_{11} \mathrm{H}_{10} \mathrm{~N}_{2} \mathrm{~S}$ & 3.60 & 3.28 & 2.62 & 60.49 & 60.44 & 603.81 & 430.79 \\
\hline 3 & $\mathrm{C}_{11} \mathrm{H}_{10} \mathrm{~N}_{2} \mathrm{~S}$ & 4.01 & 3.75 & 2.62 & - & - & 603.81 & 430.79 \\
\hline 4 & $\mathrm{C}_{12} \mathrm{H}_{12} \mathrm{~N}_{2} \mathrm{OS}$ & 3.47 & 3.03 & 2.75 & 67.74 & 66.90 & 628.14 & 324.58 \\
\hline 5 & $\mathrm{C}_{11} \mathrm{H}_{10} \mathrm{~N}_{2} \mathrm{OS}$ & 3.48 & 3.08 & 2.33 & 62.69 & 62.32 & 616.47 & 325.79 \\
\hline 6 & $\mathrm{C}_{12} \mathrm{H}_{12} \mathrm{~N}_{2} \mathrm{OS}$ & 3.76 & 3.33 & 2.79 & 67.29 & 67.07 & 628.15 & 334.21 \\
\hline 7 & $\mathrm{C}_{17} \mathrm{H}_{14} \mathrm{~N}_{2} \mathrm{~S}$ & 5.25 & 4.85 & 3.89 & 84.73 & 85.10 & 683.70 & 597.45 \\
\hline 8 & $\mathrm{C}_{17} \mathrm{H}_{14} \mathrm{~N}_{2} \mathrm{OS}$ & 4.86 & 4.57 & 3.50 & 86.54 & 86.80 & 718.54 & 442.83 \\
\hline 9 & $\mathrm{C}_{18} \mathrm{H}_{16} \mathrm{~N}_{2} \mathrm{OS}$ & 5.12 & 4.60 & 4.02 & 91.97 & 91.57 & 707.36 & 491.24 \\
\hline 10 & $\mathrm{C}_{17} \mathrm{H}_{13} \mathrm{~N}_{3} \mathrm{O}$ & 3.54 & 3.51 & 1.57 & 82.61 & 82.34 & 715.69 & - \\
\hline 11 & $\mathrm{C}_{18} \mathrm{H}_{15} \mathrm{~N}_{3} \mathrm{O}$ & 3.72 & 3.61 & 2.49 & 85.17 & 85.28 & 768.36 & 513.67 \\
\hline 12 & $\mathrm{C}_{17} \mathrm{H}_{13} \mathrm{~N}_{3} \mathrm{O}_{2}$ & 3.81 & 3.70 & 1.85 & 82.56 & 83.07 & 719.19 & 320.41 \\
\hline 13 & $\mathrm{C}_{13} \mathrm{H}_{13} \mathrm{~N}_{3}$ & 3.13 & 3.08 & 1.98 & 67.69 & 67.35 & 635.65 & 564.91 \\
\hline 14 & $\mathrm{C}_{16} \mathrm{H}_{13} \mathrm{~N}_{3} \mathrm{O}_{2}$ & 3.23 & 3.41 & 1.48 & 80.46 & 80.29 & 751.09 & 313.12 \\
\hline 15 & $\mathrm{C}_{17} \mathrm{H}_{14} \mathrm{~N}_{2} \mathrm{O}$ & 4.61 & 4.70 & 2.32 & - & - & 693.90 & 427.51 \\
\hline 16 & $\mathrm{C}_{11} \mathrm{H}_{11} \mathrm{~N}_{3} \mathrm{O}$ & 2.43 & 2.53 & 0.08 & - & - & 652.32 & 331.03 \\
\hline 17 & $\mathrm{C}_{17} \mathrm{H}_{14} \mathrm{~N}_{2} \mathrm{O}_{2}$ & 4.22 & 4.41 & 1.93 & - & - & 728.73 & 272.89 \\
\hline 18 & $\mathrm{C}_{17} \mathrm{H}_{13} \mathrm{ClN}_{2} \mathrm{O}$ & 5.17 & 5.21 & 2.94 & - & - & 712.59 & 405.95 \\
\hline 19 & $\mathrm{C}_{18} \mathrm{H}_{13} \mathrm{ClN}_{2} \mathrm{O}$ & 5.56 & 5.54 & 3.42 & - & - & 703.41 & 422.27 \\
\hline 20 & $\mathrm{C}_{5} \mathrm{H}_{7} \mathrm{~N}_{3} \mathrm{~S}$ & 1.41 & 1.11 & 0.37 & 40.57 & 40.69 & 552.64 & 334.31 \\
\hline
\end{tabular}

Table 2: 2-D Properties of substituted pyrimidine class of compounds.

\begin{tabular}{|c|c|c|c|c|c|c|c|c|c|}
\hline Mol. No. & $\begin{array}{l}\text { Molecular } \\
\text { Formula }\end{array}$ & Stretch & Bend & Stretch-Bend & Torsion & Non-VDW & 1,4 VDW & Dipole-Dipole & Total \\
\hline 1 & $\mathrm{C}_{11} \mathrm{H}_{10} \mathrm{~N}_{2} \mathrm{~S}$ & 0.4679 & 1.6023 & 0.0769 & -7.4080 & -0.0836 & 7.9171 & 0.0874 & 2.6600 \\
\hline 2 & $\mathrm{C}_{11} \mathrm{H}_{10} \mathrm{~N}_{2} \mathrm{~S}$ & 0.4536 & 1.5826 & 0.0769 & -7.4070 & -0.0756 & 7.8998 & 0.0086 & 2.5387 \\
\hline 3 & $\mathrm{C}_{11} \mathrm{H}_{10} \mathrm{~N}_{2} \mathrm{~S}$ & 0.4553 & 1.5485 & 0.0907 & -7.4054 & -0.1845 & 8.3476 & 0.0923 & 2.9446 \\
\hline 4 & $\mathrm{C}_{12} \mathrm{H}_{12} \mathrm{~N}_{2} \mathrm{OS}$ & 0.6655 & 3.9386 & 0.1199 & -7.4004 & 0.2273 & 10.4265 & 0.0390 & 8.0164 \\
\hline 5 & $\mathrm{C}_{11} \mathrm{H}_{10} \mathrm{~N}_{2} \mathrm{OS}$ & 0.7059 & 3.2110 & 0.1281 & -6.6843 & 0.6514 & 9.7856 & 1.9027 & 9.7003 \\
\hline 6 & $\mathrm{C}_{12} \mathrm{H}_{12} \mathrm{~N}_{2} \mathrm{OS}$ & 0.5808 & 3.0756 & 0.1265 & -3.4796 & -1.7792 & 10.2514 & 1.7439 & 10.5194 \\
\hline 7 & $\mathrm{C}_{17} \mathrm{H}_{14} \mathrm{~N}_{2} \mathrm{~S}$ & 0.8220 & 2.8003 & 0.1184 & -17.7450 & 0.7909 & 11.9247 & -0.1452 & -1.4338 \\
\hline 8 & $\mathrm{C}_{17} \mathrm{H}_{14} \mathrm{~N}_{2} \mathrm{OS}$ & 0.8259 & 3.3234 & 0.0963 & -17.7251 & 0.1851 & 10.6847 & -0.2133 & -2.8230 \\
\hline 9 & $\mathrm{C}_{18} \mathrm{H}_{16} \mathrm{~N}_{2} \mathrm{OS}$ & 1.0288 & 5.1841 & 0.1695 & -17.7237 & 0.9901 & 14.4348 & -0.2061 & 3.8775 \\
\hline 10 & $\mathrm{C}_{17} \mathrm{H}_{13} \mathrm{~N}_{3} \mathrm{O}$ & 0.6951 & 3.2768 & 0.0924 & -6.2121 & -0.5849 & 11.5551 & 1.9317 & 10.9540 \\
\hline 11 & $\mathrm{C}_{18} \mathrm{H}_{15} \mathrm{~N}_{3} \mathrm{O}$ & 0.8500 & 5.5708 & 0.1259 & -14.8991 & 0.5644 & 10.4201 & -3.4335 & -0.8014 \\
\hline 12 & $\mathrm{C}_{17} \mathrm{H}_{13} \mathrm{~N}_{3} \mathrm{O}_{2}$ & 1.1430 & 4.5557 & -0.0015 & -10.6674 & -0.5448 & 13.1351 & 6.3619 & 13.9820 \\
\hline 13 & $\mathrm{C}_{13} \mathrm{H}_{13} \mathrm{~N}_{3}$ & 0.3561 & 3.6110 & 0.0366 & -6.2069 & -1.9629 & 8.6348 & -1.0560 & 3.4126 \\
\hline 14 & $\mathrm{C}_{16} \mathrm{H}_{13} \mathrm{~N}_{3} \mathrm{O}_{2}$ & 0.8275 & 4.1667 & 0.0415 & -15.3315 & 0.2379 & 9.0554 & -0.8409 & -1.8433 \\
\hline 15 & $\mathrm{C}_{17} \mathrm{H}_{14} \mathrm{~N}_{2} \mathrm{O}$ & 0.8746 & 2.5200 & 0.1457 & -15.7578 & 0.6271 & 12.8771 & 1.3795 & 2.6663 \\
\hline 16 & $\mathrm{C}_{11} \mathrm{H}_{11} \mathrm{~N}_{3} \mathrm{O}$ & 0.4925 & 2.0161 & 0.1034 & -8.2174 & -0.4160 & 8.1259 & 1.397 & 3.1441 \\
\hline 17 & $\mathrm{C}_{17} \mathrm{H}_{14} \mathrm{~N}_{2} \mathrm{O}_{2}$ & 0.8671 & 3.0113 & 0.1263 & -15.8018 & 0.1279 & 11.6509 & 1.2829 & 1.2647 \\
\hline 18 & $\mathrm{C}_{17} \mathrm{H}_{13} \mathrm{CIN}_{2} \mathrm{O}$ & 0.8947 & 2.6113 & 0.1503 & -15.7608 & 0.4547 & 13.2090 & 1.3420 & 2.9011 \\
\hline 19 & $\mathrm{C}_{18} \mathrm{H}_{13} \mathrm{CIN}_{2} \mathrm{O}$ & 0.7648 & 2.3293 & 0.1179 & -9.0944 & -0.8120 & 12.7959 & 2.5368 & 8.6384 \\
\hline 20 & $\mathrm{C}_{5} \mathrm{H}_{7} \mathrm{~N}_{3} \mathrm{~S}$ & 0.1498 & 1.6923 & 0.0102 & 1.2819 & -1.0072 & 3.5666 & -0.8438 & 4.8497 \\
\hline
\end{tabular}

Table 3: Various forms of energies of designed molecules of substituted pyrimidine class of compounds. 
Citation: Ganatra SH, Bodhe MN, Tatode PN (2013) Inhibition Studies of Pyrimidine Class of Compounds on Enoyl-Acp Reductase Enzyme. J Comput Sci Syst Biol 6: 025-034. doi:10.4172/jcsb.1000097

the best ligand conformation inside the active site of enzyme so as to provide maximum interaction and stability of complex.

In present study, both types of docking were performed. To use the docking software various parameters needs to be adjusted and tuned. Table 5 depicts the various parameters used for Non-Genetic and Genetic algorithms used for docking. The docking procedure is explained in Autodock manual [20] and used as it is.

\section{Validating the docking model by known drugs}

Before docking the prepared set of molecules the model needs validation and hence, the known drugs Dapson, Clofazimine and Rifampicin were docked with the selected enzyme. The docking results for these known drugs are depicted in table 6.

The known drugs interact with enzyme and successfully docked. The reported binding energies are negative and the ligand-enzyme complexes are stable. The results of known drugs are validating the docking methodology as the drugs are already interacting with selected binding site in vitro. The higher negative value of free energy is also supporting the validity of docking methodology. Though docking procedure does have $\pm 1.0 \mathrm{kcal}$ molprecision, still the results are supporting our model to be used for the unknown molecules.

\section{Docking experiment}

Binding energy calculation: Docking algorithm makes use of force field equations and parameters to calculate the binding energy. The binding free energy is the sum of intermolecular interactions between ligand and enzyme. The interactions include van der Waals, H-bond, electrostatic and steric energy of the ligand-enzyme complex. It can be represented by the equation 2 [21-23].

$$
E_{\text {Dock }}=E_{v d w}+E_{H-\text { bond }}+E_{\text {Electrostatic }}+E_{\text {Internal }}
$$

Docking the molecule with receptor enzyme: Library of

\begin{tabular}{|l|l|}
\hline CPU & AMD-Athalone 3.0 \\
\hline Mother board & Asus \\
\hline RAM & $4 \mathrm{~GB}, 444 \mathrm{mhz}$. \\
\hline Operating system & Linux : Fedora core 5 \\
\hline Docking software name and version. & $\begin{array}{l}\text { AUTODOCK (Automated Docking } \\
\text { of Flexible Ligands to Receptors ) } \\
\text { Version:3.0.5 }\end{array}$ \\
\hline
\end{tabular}

Table 4: Details of hardware and software used to execute AUTODOCK.

$$
\text { Grid Resolution }=0.4
$$

Number Of Steps $=150$

Parameters for Genetic Algorithm Docking
The population size $=100$
Maximum Generation $=5000$
Elitism Number $=5$
Crossover Rate $=0.8$
Mutation Rate $=0.2$
Local Search Rate $=0.06$
Local Search Maximum Iteration $=20$
Converged When rmsd Population Fitness $<1$ Kcal./Mole
Grid Dimensions $=67 \times 77 \times 61$
Total Number Of Grid Points $=314699$
RMSD Calculation : 2 A with defined rotatable bonds and active torsions set to
fewest atoms
Grid Resolution $=0.4$
Grid Dimension $=40,40,40$ in $X, Y, Z$ dimensions

Table 5: Parameters for Non-Genetic Docking.

\begin{tabular}{|l|l|l|l|}
\hline \multirow{2}{*}{ Compound Name } & Molecular Formula & \multicolumn{3}{|l|}{ Binding Energy $\Delta G$ in Kcal./Mol. } \\
\cline { 3 - 5 } & $\begin{array}{l}\text { Non - GA } \\
\text { Docking }\end{array}$ & GA Docking \\
\hline Dapson & $\mathrm{C}_{12} \mathrm{H}_{12} \mathrm{~N}_{2} \mathrm{O}_{2} \mathrm{~S}$ & -11.8823 & -11.6732 \\
\hline Clofazimine & $\mathrm{C}_{27} \mathrm{H}_{22} \mathrm{C}_{12} \mathrm{~N}_{4}$ & -10.1769 & -10.1354 \\
\hline Rifampicin & $\mathrm{C}_{43} \mathrm{H}_{58} \mathrm{~N}_{4} \mathrm{O}_{12}$ & -10.69999 & -10.5495 \\
\hline
\end{tabular}

Table 6: Docking results for known drugs of Leprosy.

Pyrimidine class of compounds were prepared and supplied to the docking software. The AUTODOCK software parameters set as per the instructions provided in user manual [20,23]. The lists of parameters and their values for Non-GA and GA docking are shown in table 4. The parameter setting unchanged throughout the experiment. The Non-GA and GA docking results obtained for the pyrimidine class of compounds are depicted in table 7.

Cluster study: The GA docking method also provides the cluster size. It shows how many conformations have the same binding energy value. More the cluster size is, it betters the selected binding pose. Though software provides number of poses (conformations), but in present study only first 3 best poses selected and reported. Table 7 shows the observed cluster values along with the binding energies in kcal mol ${ }^{-1}$.

\section{Results}

The two types of docking methods reports nearly same binding energies but genetic algorithm method provides higher conformations (poses) of ligand in active site of enzyme.

The ligand fitting into the active site and hence higher interactions depends on the binding energies and possibilities of number of hydrogen bonds. The binding energy includes nearly all types of interactions as depicted in equation 2 . The docking results also provide the possibilities of hydrogen bonds between the atoms of ligand and amino acids. The hydrogen bond gives stable conformation to the complex and hence generally gives better drug-like properties.

From docking results, it is observed that molecule number 8, 15 and 18 show better docking values along with number of hydrogen bonds. These three molecules report binding energy less than $-10 \mathrm{kcal} \mathrm{mol}^{-1}$. All three molecules report the possibilities of two hydrogen bonds. Molecule number 8 with 98-MET and 97-PHE, molecule number 15 with 96-GLY (both bonds) and molecule number 18 with 94-SER and 14-GLYamino acids of receptor enzyme. All possible hydrogen bonds are having bond distance less than $2.9 \AA$. Table 7 lists the binding energies, cluster size, number of hydrogen bonds of molecular number 8,15 and 18 .

It is reported that 98-Methainine, 96-Glycine, 162-Threonine, 194-Isoleucine, 99-Proline, and 94-Serine are taking part in making hydrogen bonds with the ligand atoms. 98-Methianine and 96-Glycine is the most prone amino acids to make hydrogen bonds with ligand atoms.

Figures 4, 5 and 6 shows the molecule structure, molecule surface charge distribution and ligand-receptor enzyme complex (docking pictures) of molecule number 8,15 and 18. The docking pictures in wire-frame and CPK mode clearly represent the ligand placement inside the active site of receptor enzyme. 
Citation: Ganatra SH, Bodhe MN, Tatode PN (2013) Inhibition Studies of Pyrimidine Class of Compounds on Enoyl-Acp Reductase Enzyme. J Comput Sci Syst Biol 6: 025-034. doi:10.4172/jcsb.1000097

\begin{tabular}{|c|c|c|c|c|c|c|}
\hline \multirow[t]{2}{*}{ Mol. No. } & \multirow[t]{2}{*}{ Molecular Formula } & \multicolumn{2}{|c|}{$\begin{array}{l}\text { Binding Energy in } \\
\Delta \mathrm{G} \mathrm{Kcal} / \mathrm{Mol} \text {. }\end{array}$} & \multicolumn{3}{|c|}{$\begin{array}{l}\text { Binding Energy with Cluster Size } \\
\text { (Number of Conformations). } \\
\text { Value in brackets are cluster size }\end{array}$} \\
\hline & & Non - GA Docking & GA Docking & 1 & 2 & 3 \\
\hline 1 & $\mathrm{C}_{11} \mathrm{H}_{10} \mathrm{~N}_{2} \mathrm{~S}$ & -9.42 & -9.734 & $-9.7(26)$ & $-9.44(1)$ & $-8.84(2)$ \\
\hline 2 & $\mathrm{C}_{11} \mathrm{H}_{10} \mathrm{~N}_{2} \mathrm{~S}$ & -9.83 & -8.172 & $-8.1(32)$ & $-8.13(3)$ & $-8.08(4)$ \\
\hline 3 & $\mathrm{C}_{11} \mathrm{H}_{10} \mathrm{~N}_{2} \mathrm{~S}$ & -9.20 & -8.071 & $-8.07(10)$ & $-8.05(21)$ & $-7.69(2)$ \\
\hline 4 & $\mathrm{C}_{12} \mathrm{H}_{12} \mathrm{~N}_{2} \mathrm{OS}$ & -8.87 & -8.324 & $-8.3(17)$ & $-8.09(2)$ & $-7.61(1)$ \\
\hline 5 & $\mathrm{C}_{11} \mathrm{H}_{10} \mathrm{~N}_{2} \mathrm{OS}$ & -9.84 & -8.208 & $-8.21(36)$ & $-8.10(6)$ & $-7.50(1)$ \\
\hline 6 & $\mathrm{C}_{12} \mathrm{H}_{12} \mathrm{~N}_{2} \mathrm{OS}$ & -9.74 & -8.912 & $-8.9(23)$ & $-8.40(1)$ & $-8.18(1)$ \\
\hline 7 & $\mathrm{C}_{17} \mathrm{H}_{14} \mathrm{~N}_{2} \mathrm{~S}$ & -12.62 & -12.58 & $-12.5(8)$ & $-11.85(3)$ & $-11.65(2)$ \\
\hline 8 & $\mathrm{C}_{17} \mathrm{H}_{14} \mathrm{~N}_{2} \mathrm{OS}$ & -12.11 & -12.30 & $-12.30(19)$ & $-11.99(2)$ & $-11.98(1)$ \\
\hline 9 & $\mathrm{C}_{18} \mathrm{H}_{16} \mathrm{~N}_{2} \mathrm{OS}$ & -12.12 & -10.63 & $-10.64(14)$ & $-10.16(2)$ & $-10.08(2)$ \\
\hline 10 & $\mathrm{C}_{17} \mathrm{H}_{13} \mathrm{~N}_{3} \mathrm{O}$ & -12.50 & -10.21 & $-10.21(3)$ & $-10.19(20)$ & $-9.86(1)$ \\
\hline 11 & $\mathrm{C}_{18} \mathrm{H}_{15} \mathrm{~N}_{3} \mathrm{O}$ & -10.69 & -11.56 & $-11.5(23)$ & $-11.3(1)$ & $-11.1(1)$ \\
\hline 12 & $\mathrm{C}_{17} \mathrm{H}_{13} \mathrm{~N}_{3} \mathrm{O}_{2}$ & -12.03 & -11.36 & $-11.37(21)$ & $-11.1(1)$ & $-10.7(2)$ \\
\hline 13 & $\mathrm{C}_{13} \mathrm{H}_{13} \mathrm{~N}_{3}$ & -10.42 & -10.22 & $-10.22(15)$ & $-9.7(1)$ & $-9.5(1)$ \\
\hline 14 & $\mathrm{C}_{16} \mathrm{H}_{13} \mathrm{~N}_{3} \mathrm{O}_{2}$ & -11.14 & -11.34 & $-11.35(49)$ & $-10.5(2)$ & $-10.1(2)$ \\
\hline 15 & $\mathrm{C}_{17} \mathrm{H}_{14} \mathrm{~N}_{2} \mathrm{O}$ & -12.49 & -12.68 & $-12.68(27)$ & $-12.1(1)$ & $-11.8(1)$ \\
\hline 16 & $\mathrm{C}_{11} \mathrm{H}_{11} \mathrm{~N}_{3} \mathrm{O}$ & -9.30 & -9.89 & $-9.89(35)$ & $-9.2(3)$ & $-8.9(1)$ \\
\hline 17 & $\mathrm{C}_{17} \mathrm{H}_{14} \mathrm{~N}_{2} \mathrm{O}_{2}$ & -10.96 & -11.18 & $-11.19(34)$ & $-10.4(2)$ & $-9.6(1)$ \\
\hline 18 & $\mathrm{C}_{17} \mathrm{H}_{13} \mathrm{CIN}_{2} \mathrm{O}$ & -12.99 & -12.64 & $-12.64(29)$ & $-11.9(4)$ & $-11.7(7)$ \\
\hline 19 & $\mathrm{C}_{18} \mathrm{H}_{13} \mathrm{CIN}_{2} \mathrm{O}$ & -11.91 & -12.16 & $-12.17(12)$ & $-11.6(2)$ & $-11.3(1)$ \\
\hline 20 & $\mathrm{C}_{5} \mathrm{H}_{7} \mathrm{~N}_{3} \mathrm{~S}$ & -6.21 & -5.98 & $-5.98(12)$ & $-5.9(4)$ & $-5.7(1)$ \\
\hline
\end{tabular}

Table 7: Binding energies and cluster size for Pyrimidine class of compounds while docked with Enoyl ACP Reductase (PDB Ref. No.: 2NTV).
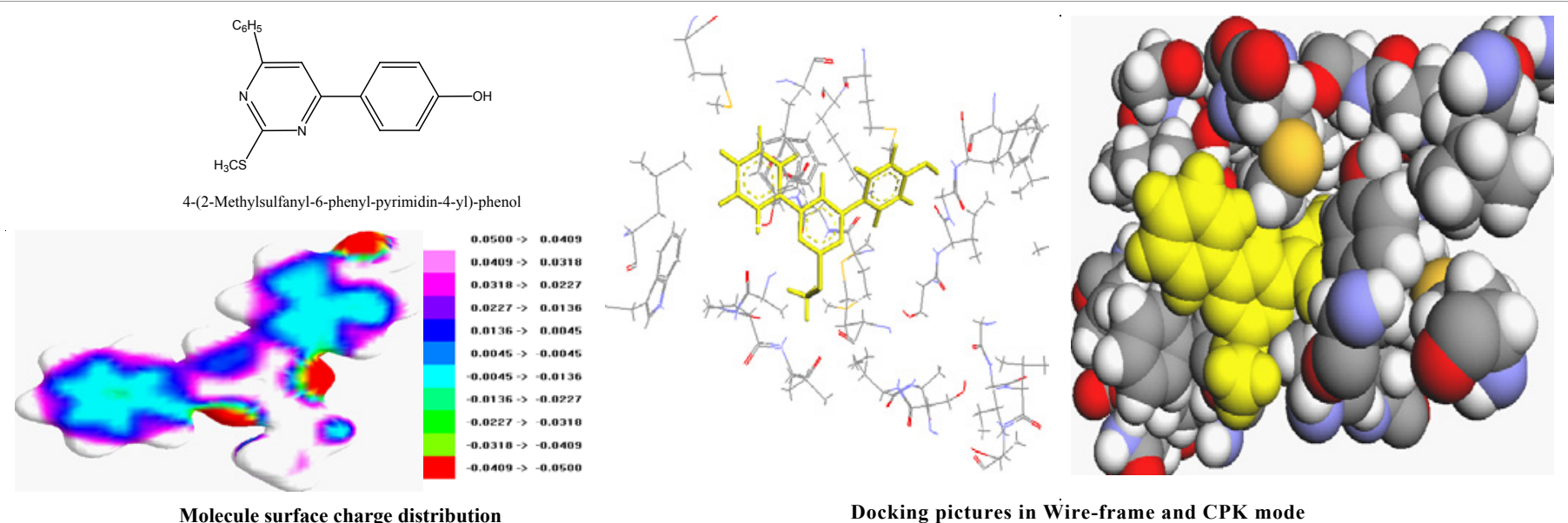

Docking pictures in Wire-frame and CPK mode

Figure 4: Molecular structure, electron charge density distribution and docking pictures of 4-(2-Methyl sulfanyl-6-phenyl-pyrimidine-4-yl)-phenol (Molecule No. 8) with Enoyl ACP Reductase (2NTV).

\section{Conclusion}

The docking results clearly indicate that molecule number 8,15 and 18 are the best docked molecules and can be further processed as anti-leprosy agents. The selected molecules show better hydrophobic, electrostatic and steric interactions with Enoyl-ACP reductase. The presence of $-\mathrm{CH}_{2} \mathrm{OH}$ at $\mathrm{R}_{1}-\mathrm{C}_{6} \mathrm{H}_{5}$ at $\mathrm{R}_{2}$ and $\mathrm{R}_{3}$ positions enhance the negative binding energy $\left(\Delta \mathrm{G}\right.$ kcal $\left.\mathrm{mol}^{-1}\right)$ values. Particularly $-\mathrm{OC}_{6} H_{5}$ at $\mathrm{R}_{1}$ helps in increasing the interactions, electrostatic groups $-\mathrm{OH}$ at $\mathrm{R}_{2}$ position also helps in enhancing the interaction for these compounds. These results show that Pyrimidine based molecule is positively interacting with Enoyl-ACP reductase (Crystal Structure PDB Ref: 2NTV).

The molecule number 8,15 and 18 definitely represent the best antileprosy agents and can be further tested in-vitro. Their binding energy values, hydrogen bonds and number of poses (cluster value) reflect the possibilities of anti-leprosy drug-likeness and can be good therapeutic anti-leprosy agents. The druglikeness can also be supported by the 
Citation: Ganatra SH, Bodhe MN, Tatode PN (2013) Inhibition Studies of Pyrimidine Class of Compounds on Enoyl-Acp Reductase Enzyme. J Comput Sci Syst Biol 6: 025-034. doi:10.4172/jcsb.1000097

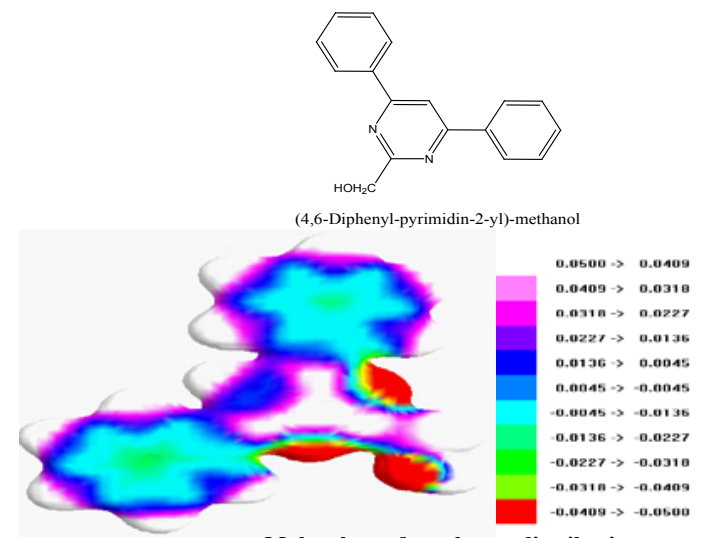

Molecule surface charge distribution

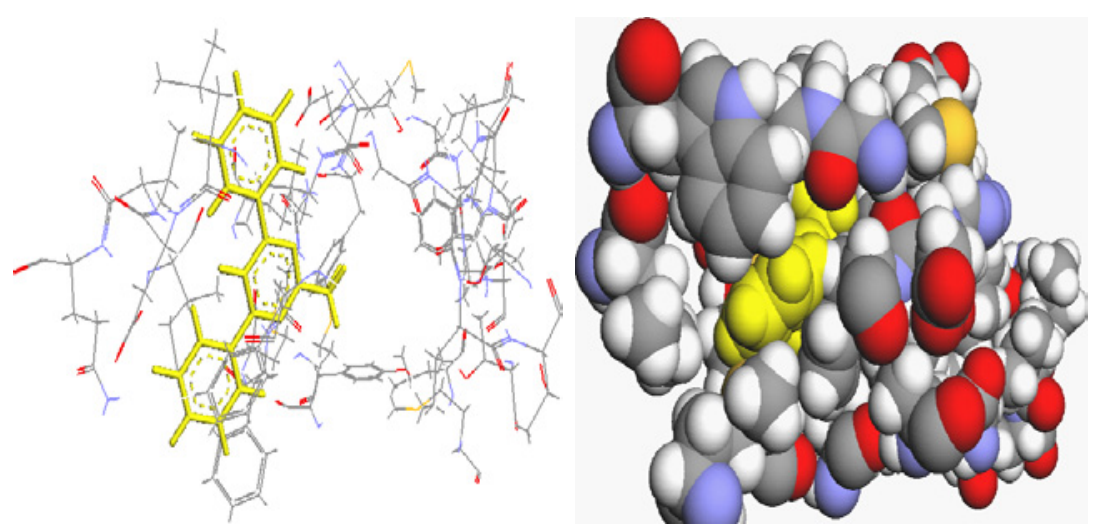

Docking pictures in Wire-frame and CPK mode

Figure 5: Molecular structure, electron charge density distribution and docking pictures of (4,6-Diphenyl-pyrimidine-2-yl)-methanol (Molecule No. 15) with Enoyl-ACP Reductase (2NTV).

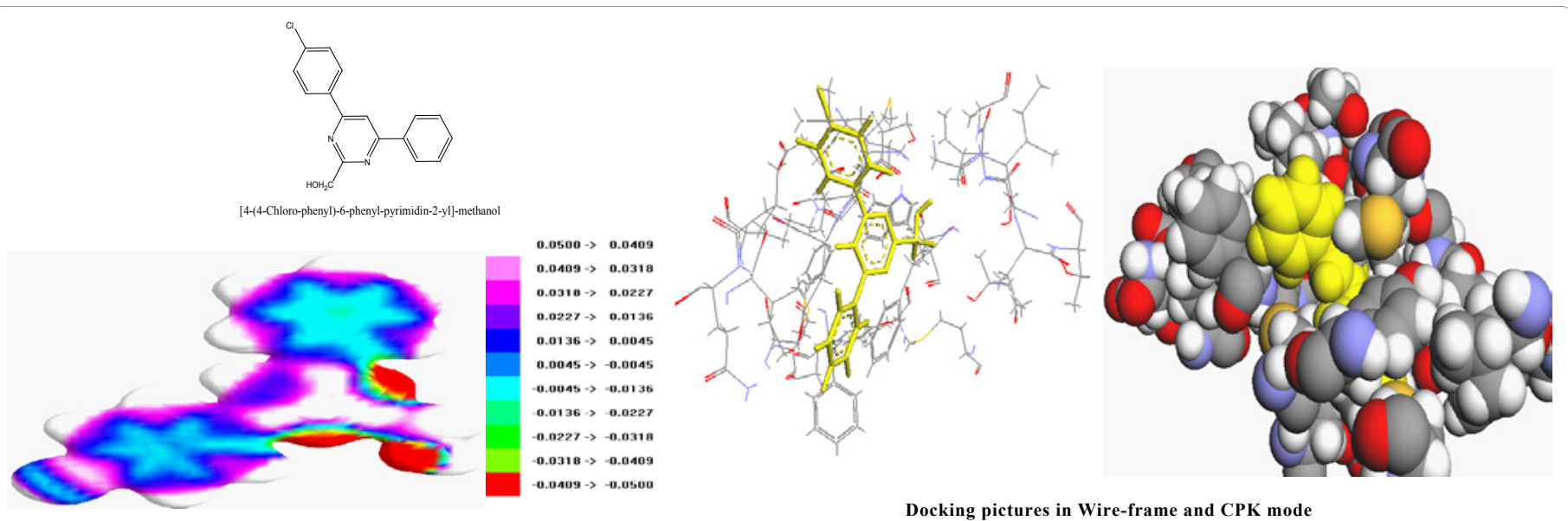

Figure 6: Molecular structure, electron charge density distribution and docking pictures of [4-(4-chloro-phenyl)-6-phenyl-pyrimidine-2-yl]-methanol (Molecule No. 18) with Enoyl-ACP Reductase (2NTV).

$\log \mathrm{P}$ values. Table 2 provides the $\log \mathrm{P}$ values for all studied molecules using three methods. It is reported that molecule number 8,15 and 18 are having LogP values less than 5 as per Broto's fragmentation method which supports the probable property of anti-leprosy agents in selected molecules.

The clinical studies on these molecules by expert from that field can focus more on the possibilities of drug likeness by knowing the experimental biological activities and toxicities.

\section{References}

1. Sasaki S, Takeshita F, Okuda K, Ishii N (2001) Mycobacterium leprae and leprosy: a compendium. Microbiol Immunol 45: 729-736.

2. Ray CG, Sherris JC (2004) Sherris medical microbiology: an introduction to infectious diseases (4th edn) McGraw Hill, New York.

3. [No authors listed] (1995) Leprosy disabilities: magnitude of the problem. Wkly Epidemiol Rec 70: 269-275.

4. Jopling WH (1991) Leprosy stigma. Lepr Rev 62: 1-12.

5. Wang F, Langley R, Gulten G, Dover LG, Besra GS, et al. (2007) Mechanism of thioamide drug action against tuberculosis and leprosy. J Exp Med 204: 73-78.

6. Keenan SM, Geyer JA, Welsh WJ, Prigge ST, Waters NC (2005) Rational inhibitor design and iterative screening in the identification of selective plasmodial cyclin dependent kinase inhibitors. Comb Chem High Throughput Screen 8: 27-38.

7. Richards WG (1994) Computer aided drug design, Pure \& Appl Chem 66 1589-1596.

8. Schoepfer J, Fretz H, Chaudhuri B, Muller L, Seeber E, et al. (2002) Structurebased design and synthesis of 2-benzylidene-benzofuran-3-ones as flavopiridol mimics. J Med Chem 45: 1741-1747.

9. Boyd DB (1995) Reviews in Computational Chemistry (6thedn). VCH, New York.

10. WarshelA (1991) Computer Modeling of Chemical Reactions in Enzymes and Solutions. Wiley, New York.

11. Clementi E (1980) Computational Aspects for Large Chemical Systems Springer-Verlag, New York.

12. Kapoor M, Gopalakrishnapai J, Surolia N, Surolia A (2004) Mutational analysis of the triclosan-binding region of enoyl-ACP (acyl-carrier protein) reductase from Plasmodium falciparum. Biochem J 381: 735-741.

13. Dugan RE, Slakey LL, Porter JW (1970) Stereospecificity of the transfer of hydrogen from reduced nicotinamide adenine dinucleotide phosphate to the acyl chain in the dehydrogenase-catalyzed reactions of fatty acid synthesis. J Biol Chem 245: 6312-6316.

14. Dutta S, M Berman H, F Bluhm W (2007) Using the tools and resources of the RCSB protein data bank. Curr Protoc Bioinformatics Chapter 1: Unit1. 
Citation: Ganatra SH, Bodhe MN, Tatode PN (2013) Inhibition Studies of Pyrimidine Class of Compounds on Enoyl-Acp Reductase Enzyme. J Comput Sci Syst Biol 6: 025-034. doi:10.4172/jcsb.1000097

15. Ananthalakshmi P, Samayamohan K, Chokalingam C, Mayilarasi C, Sekar K (2005) PSST-2.0: Protein Data Bank Sequence Search Tool. Appl Bioinformatics 4: 141-145.

16. Morris GM, Goodsell DS, Halliday RS, Huey R, Hart WE, et al. (1998) Automated docking using a Lamarckian genetic algorithm and an empirical binding free energy function. J Computational Chemistry 19: 1639-1662.

17. Chemdraw Software, Cambridge Corporation, Cambridge M.A. 02140 U.S.A

18. McQuarrie DA (1983) Quantum Chemistry. University Science Books, Michigan.

19. Cohen-Tannoudji C, Diu B, Laloe F (1997) Quantum Mechanics Volumes I and II, Wliey-Interscience.
20. Morris GM, Huey R, Lindstrom W, Sanner MF, Belew RK, et al. (2009) AutoDock4 and AutoDockTools4: Automated docking with selective receptor flexibility. J Comput Chem 30: 2785-2791.

21. Jensen F (1999) Introduction to Computational Chemistry. John Wiley \&Sons New Jersey.

22. Raha K, Merz KM Jr (2005) Large-scale validation of a quantum mechanics based scoring function: predicting the binding affinity and the binding mode of a diverse set of protein-ligand complexes. J Med Chem 48: 4558-4575.

23. Patle M, Ganatra SH (2011) In-Silico Inhibition Studies of Phenothiazine Based Compounds on Quinolinic Acid Phosphoribosyltransferase (1QPQ) Enzyme as A Potent Anti-Tuberculosis Agent. Asian J Research Chem 4: 990-996. 